\title{
CHARACTERIZATION AND USE OF SWINE DEEP BEDDING ASHES IN CEMENTITIOUS COMPOSITES
}

\author{
DÉBORA C. G. DE OLIVEIRA ${ }^{1}$, MICHELLE S. RODRIGUES ${ }^{2}$, \\ SÉRGIO F. DOS SANTOS ${ }^{3}$, HOLMER SAVASTANO JUNIOR ${ }^{4}$
}

\begin{abstract}
The deep bedding is a swine alternative production, especially in the finishing phase, whose byproduct can be recycled, reducing the environmental impact. The objectives of this study were to characterize the ash coming from the controlled burning of the swine deep bedding (SDBA) based on rice husk, and to evaluate their performance in composites as a partial substitute for Portland cement (PC). To measure the differences between SDBA and rice husk ash (RHA) as a reference, we have characterized: particle size distribution, real specific density, x-ray diffraction, electrical conductivity, scanning electron microscopy, chemical analysis and loss on ignition. Samples were prepared for two experimental series: control, and another one with the partial replacement of $30 \%$ of SDBA in relation to the mass of the Portland cement. According to the results obtained for physical and mechanical characterization, the composites with SDBA can be used as a constructive element in the rural construction.
\end{abstract}

KEYWORDS: composite, rural construction, residues, swine production, sustainability.

\section{CARACTERIZAÇÃO DA CINZA DE CAMA SOBREPOSTA DE SUÍNOS E SEU APROVEITAMENTO EM COMPÓSITOS CIMENTÍCIOS}

RESUMO: A cama sobreposta é uma alternativa de produção suinícola, principalmente na fase de terminação, cujo subproduto pode ser reciclado, com diminuição do impacto ambiental. Assim, os objetivos deste trabalho foram caracterizar a cinza oriunda da queima controlada da cama sobreposta de suínos (CCSS) à base de casca de arroz e avaliar seu desempenho em compósitos como substituto parcial do cimento Portland (CP). Para mensurar as diferenças entre CCSS e cinzas de casca de arroz (CCA) como referência, foram caracterizadas: distribuição granulométrica, massa específica real, difração de raios X, condutividade elétrica, microscopia eletrônica de varredura, análise química e perda ao fogo. Foram confeccionadas duas séries de corpos de prova, de controle e com substituição parcial, utilizando $30 \%$ da CCSS em relação ao Cimento Portland. De acordo com os resultados obtidos quanto à caracterização física e mecânica, os compósitos com CCSS podem ser utilizados como elemento construtivo no meio rural.

PALAVRAS-CHAVE: compósito, construção rural, resíduos, suinocultura, sustentabilidade.

\section{INTRODUCTION}

The demand for appropriate materials, allied to sustainable production model, requires that the swine production to be increasingly technified. It is noticed that many barriers are applied to the exportation of swine meat, and it is possible to highlight those related to the creation, based on animal welfare and environmental care (OLIVEIRA, 2010).

The breeding system most adopted in finishing pigs is the kind of total or partialslatted, and these production systems require the use of manure deposits or ponds for storage of manure, investments which are not always compatible with the economic reality of the producers. Thus, the production of deep bedding system is an alternative in which the waste suffers composting "in situ"

\footnotetext{
${ }^{1}$ Doutoranda em Engenharia de Alimentos, Faculdade de Zootecnia e Engenharia de Alimentos, USP.

${ }^{2}$ Dra. em Engenharia Agrícola, Universidade Estadual de Campinas.

${ }^{3}$ Bacharel em Física, Pós-doutorando, Faculdade de Zootecnia e Engenharia de Alimentos, USP.

${ }^{4}$ Pofessor Titular, Faculdade de Zootecnia e Engenharia de Alimentos, USP.

Recebido pelo Conselho Editorial em: 31-10-2011

Aprovado pelo Conselho Editorial em: 25-5-2012
} 
in order to reduce the risk of pollution of air, water and soil and to have better agronomic value. In the search for alternatives to the use of this bed, mostly used as fertilizer, there is also the possibility of burning.

There is an immediate need to employ alternative materials in constructions, due to the high cost of building materials, and increasing environmental concerns, due to intensive exploitation of natural resources related to construction in general. The use of agricultural waste has become a necessity due to the high environmental cost derived from its inappropriate disposal in nature. The rice husk ash and its combinations are a potential residue.

The use of ash from the controlled burning of swine deep bedding (SDBA) based on the rice husks may contribute to the reduction of emission of $\mathrm{CO}_{2}$ in the air and release of ammonia $\left(\mathrm{NH}_{3}\right)$ in the soil, in order to reduce shipping costs, to aggregate value to the final product, and also to enable the swine producer to have direct access to a good performance of pozzolanic material to reduce costs in buildings (OLIVEIRA, 2010).

The objectives of this study were to characterize the ash from the controlled burning of swine deep bedding (SDBA) to be used as a partial replacement of Portland cement, and to evaluate its performance in composites.

\section{MATERIAL AND METHODS}

This study was conducted at the Faculty of Animal Science and Food Engineering, campus of University of São Paulo, located in Pirassununga, state of São Paulo, Brazil, and it was divided into the following steps:

\section{a) Production of RHA and SDBA}

The swine deep bedding (SDB), based on rice husk and used in the finishing phase, was from São Paulo's Agency for Agribusiness Technology (APTA) - Southwest Pole of the State of São Paulo, Research and Development Unity located at Itapeva, São Paulo State, Brazil. Samples were ollected at random points of the installation, homogenized and packaged appropriately for further characterization.

The SDB was initially burned in a muffle furnace (Jung brand / model 10010) with a heating ramp of $5{ }^{\circ} \mathrm{C} / \mathrm{min}$, at $600^{\circ} \mathrm{C}$ for $3 \mathrm{~h}$, and then cooled naturally. The same procedure was performed with rice husk $(\mathrm{RH})$. After burning and cooling process, these materials were placed in porcelain jar of 7.5 L of volume, containing 32 balls (24-26 mm diameter) at a speed of $200 \mathrm{rpm}$, in a rotary ball mill (trade Tecnal / model TE-500) for $240 \mathrm{~min}$, forming the swine deep bedding ashes (SDBA) and rice husk ash (RHA), as the procedure mentioned by OLIVEIRA (2010).

\section{b) Raw material characterization}

The samples of RHA, the SDBA and Portland Cement PC V-ARI (NBR 5733/1991) were analyzed for chemical composition by x-ray fluorescence spectrometry and loss on ignition. We also carried out with x-ray diffraction using diffractometer (Philips brand / model MDP 1880), in samples RHA and SDBA. The identification of crystal phases was carried out by means of a database PDF2 of the ICCD - International Centre for Diffraction Data (2003) and PAN-ICSDPAN analytical Inorganic Crystal Structure Database (2007).

The particle morphology of the RHA and the SDBA was performed by scanning electron microscopy (SEM) and energy-dispersive X-ray spectroscopy (EDS) using a scanning electron microscope (Quanta 600 FEG), allowing determination of composition of chemical elements.

The particle size distributions of the RHA, SDBA, Portland Cement of high early strength (PC V-ARI) and medium coarse sand (NBR 7214/1982) and the respective equivalent diameter of the particles were determined by low angle scattering laser (Malvern brand / model MMS Mastersizer). It was determined the real specific density of RHA, SDBA, PC V-ARI and sand using a helium multipycnometer (Quantachrome brand / Ultrapycnometer 100). 
The pozzolanicity of RHA and SDBA was assessed by electrical conductivity measuments for the semi-quantitative evaluation of the reactivity. This method is to evaluate semi-quantitatively the reactivity of ashes with unsaturated solution of calcium hydroxide $\mathrm{Ca}(\mathrm{OH})_{2}$, according to the procedure proposed by PAYÁ et al. (2001) and OYEKAN \& KAMIYO (2011), when evaluating the rate of decrease in electrical conductivity in suspension.

\section{Preparation of composites}

For the physical and mechanical characterization of cementitious composites, two formulations were prepared: a reference in 1:3 ratio (cement: sand), and another in 0.7:0.3:3 (cement: SDBA: sand), with water cement factor of $0.6(\mathrm{w} / \mathrm{c}=0.6)$, as shown in Table 1.

TABLE 1 . Formulations of cementitious composites by percentage of dry matter (\%).

\begin{tabular}{lcc}
\hline Raw Material & Reference & Composite \\
\hline PC V-ARI & 25 & 17.5 \\
Sand & 75 & 75 \\
Swine Deep Bedding Ash & --- & 7.5 \\
\hline
\end{tabular}

The mixture of these materials was done in a planetary mixer (Cairo Metal brand / model AG5) with a tank capacity of $5 \mathrm{~L}$, and low speed of $62 \pm 5 \mathrm{rpm}$, in the following sequence: PC VARI and sand were initialy mixed for 5 min, adding water slowly until homogeneous dough for reference. The same procedures were performed by placing the SDBA together with cement and sand. To prepare the plates (square geometry), the mortar was poured in a wooden frame with metallic background with was compacted by vibration for 4 min, using a vibrating table with flat surface, set in motion by a motor of $3 \mathrm{~kW}$ and with vibration frequency of $2200 \mathrm{rpm}$.

After the plates were molded, they were placed in a tray completely sealed with plastic for two days, and two plates were prepared for each formulation, with dimensions $200 \mathrm{~mm}$ x $200 \mathrm{~mm} \times$ $14 \mathrm{~mm}$. Then, curing was performed, in which one plate ofeach formulation was immersed in water for eight days and the other plate was immersed for 26 days, of each formulation. The plates of 10 and 28 days old were cut into circular saw cooled by water, with diamond disk, ensuring the integrity of the test specimens, used in the nominal dimension of $160 \mathrm{~mm} \times 40 \mathrm{~mm} \times 14 \mathrm{~mm}$ and tested in saturated water condition, due to the curing process adopted; before the bending test the excess of water was removed from the surfaces of the plate with a cloth.

The mechanical tests were performed on a universal testing machine (EMIC brand / model DL-30000), according to RILEM (1984). The configuration used was the one at four points bending, as shown in Figure 1, with the spam between lower supports equal to $135 \mathrm{~mm}$ and with equal distance between higher supports equal to $45 \mathrm{~mm}$, with a load cell of $5 \mathrm{kN}$ and deflectometer of EMIC brand, EE05-ESP model, for measuring the deformation in $\mathrm{mm}$. The rate of load application was $1.5 \mathrm{~mm} / \mathrm{min}$. The specific deformation was calculated based on the values of the deformation obtained by deflectometer, divided by the distance between lower supports.

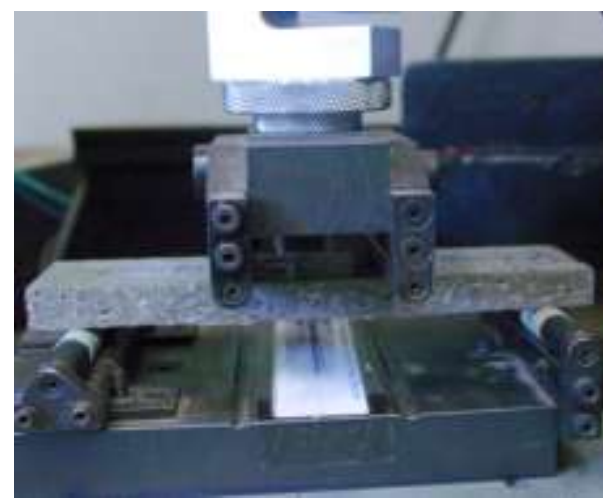

FIGURE 1. Four-point bending device with a specimen and load cell. 
In the mechanical tests, the following properties were obtained: modulus of rupture (MOR) and modulus of elasticity (MOE), as procedure quoted by TONOLI et al. (2007). The physical tests were applied for water absorption, bulk density and apparent porosity using the law of Archimedes principle (NBR 15498/2007). For statistical analysis of physical and mechanical tests, it was used a completely randomized design to compare the means and the Tukey test at a confidence level of $95 \%(\mathrm{P}<0.05)(\mathrm{SAS}, 2006)$.

\section{RESULTS AND DISCUSSION}

\section{Characterization of raw materials}

The values of specific density of raw materials are shown in Table 2.

TABLE 2. Values of the real specific density

\begin{tabular}{lc}
\hline Raw Material & Real Specific Density $\left(\mathrm{g} / \mathrm{cm}^{3}\right)$ \\
\hline PC V-ARI & 3.09 \\
Sand & 2.65 \\
Rice husk ash (RHA) & 2.29 \\
Swine Deep Bedding Ash (SDBA) & 2.55 \\
\hline
\end{tabular}

The real density of SDBA is related to the amount of organic material and, consequently, the temperature of calcination. The increase in temperature leads to reducing the amount of volatile substances and, consequently, increased internal porosity of the ash, thus interfering in density as reported by DI CAMPOS (2010). However, the specific density of a chemical compound is intrinsically related to the number of atoms associated with each unitary cell, atomic weight and volume of the unitary cell. Often, a modification of the specific density of a chemical compound follows the polymorphic transformation which may occur, for instance, by applying a heat treatment (CALLISTER, 2007). Thus, the real specific density of the SDBA is directly related to its chemical composition (Table 3). Furthermore, it is known that the swine deep bedding consists of base material (rice husk) and and other materials generated during the productive cycle, which also interfere with the specific density of ashes.

Table 3 lists the chemical compounds of PC V-ARI, RHA and SDBA.

TABLE 3. Chemical analysis of cement PC V-ARI and of RHA and SDBA (\% by mass).

\begin{tabular}{cccc|cccc|cccc}
\hline & PC & RHA & SDBA & & PC & RHA & SDBA & & PC & RHA & SDBA \\
\hline $\mathrm{Na}_{2} \mathrm{O}$ & 0.48 & 0.17 & 1.33 & $\mathrm{Cl}$ & nd & 0.12 & 0.90 & $\mathrm{Fe}_{2} \mathrm{O}_{3}$ & 2.75 & 0.17 & 2.49 \\
$\mathrm{MgO}$ & 1.55 & 0.64 & 2.48 & $\mathrm{~K} 2 \mathrm{O}$ & 1.13 & 2.07 & 5.4 & $\mathrm{ZnO}$ & 0.01 & 0.01 & 0.19 \\
$\mathrm{Al}_{2} \mathrm{O}_{3}$ & 3.59 & 0.29 & 4.55 & $\mathrm{CaO}$ & 65.2 & 0.88 & 5.66 & $\mathrm{Br}$ & nd & $<<$ & $<$ \\
$\mathrm{SiO}_{2}$ & 18.1 & 93.9 & 64.4 & $\mathrm{TiO}_{2}$ & 0.27 & 0.04 & 0.40 & $\mathrm{Rb}_{2} \mathrm{O}$ & 0.01 & 0.01 & 0.01 \\
$\mathrm{P}_{2} \mathrm{O}_{5}$ & 0.17 & 1.00 & 5.15 & $\mathrm{~V}_{2} \mathrm{O}_{5}$ & $<<$ & nd & $<<$ & $\mathrm{SrO}$ & 0.23 & $<<$ & 0.04 \\
$\mathrm{SO}_{3}$ & 6.41 & 0.47 & 2.54 & $\mathrm{MnO}$ & 0.06 & 0.17 & 0.12 & LOI & 0 & 0.03 & 4.11 \\
\hline
\end{tabular}

* nd: element not detected; <<: traces (lower than $0.01 \%$ ). LOI $=$ loss on ignition.

The chemical composition of cement PCV-ARI meets the specifications of ISO 5733 (1991). The chemical composition of RHA varies depending on soil types and levels of fertilizers used; the amount of $\mathrm{SiO}_{2}$ obtained in the RHA in the present study was $93.9 \%$, considering that POSSAN et al. (2007) and RODRIGUES \& BERALDO (2010) found, respectively, 86.5 and $96.1 \%$.

The loss on ignition of $0.03 \%$ indicates that the heat treatment used for burning of rice husks was sufficiently adequate to remove all organic matter. However, the value obtained by SDBA $(4.11 \%)$ could be related mainly to the presence of impurities in the sample, such as hydroxides and organic matter (SOUZA et al., 2003). 
The SDBA presented $\mathrm{SiO}_{2}$ content of $64.4 \%$, higher than that obtained by DI CAMPOS (2010) of $47.9 \%$ for a similar ash. This difference may be a result of productive handling of the rice and the swine deep bedding. Other variables may have the composition of the ash, as the different characteristics of liquid and solid manure, swine ration on deep bedding, which change for each barn and production cycle.

Comparing the chemical composition between RHA and SDBA, it is possible to notice that there is an increase in the levels of $\mathrm{Na}_{2} \mathrm{O}, \mathrm{P}_{2} \mathrm{O}_{5}, \mathrm{SO}_{3}, \mathrm{~K}_{2} \mathrm{O}$ and $\mathrm{CaO}$. The increase in these oxides is due to the contamination suffered by rice husk in swine breeding by liquid and solid manure (feed, feces and urine). The presence of alkali ions such as $\mathrm{K}$ and $\mathrm{Na}$ in mineral additions should be avoided, as they can cause alkali-aggregate reaction in the cement matrix (JOHN et al., 2003). According to CINCOTTO \& KAUPATEZ (1988), the minimum content of $\mathrm{SiO}_{2}$ in the pozzolan considered reactive is $44 \%$. The sum of the compounds $\left(\mathrm{SiO}_{2}, \mathrm{Al}_{2} \mathrm{O}_{3}\right.$ and $\left.\mathrm{Fe}_{2} \mathrm{O}_{3}\right)$ for SDBA obtained in this study was $71.4 \%$ and they are close to the lower limit proposed by ASTM C-618-03 (2003), which is (50\%). It can be seen in Table 4 shows the values recommended by ASTM C-61803 (2003), which represent a plurality of requirements to be considered pozzolanic material and those obtained for the SDBA.

TABLE 4. Percentage of values found in the chemical composition of swine deep bedding ashes and values defined by ASTM C-618-03.

\begin{tabular}{lcc}
\hline & SDBA (\%) & ASTM C-618-03 (\%) \\
\hline $\mathrm{SiO}_{2}+\mathrm{Al}_{2} \mathrm{O}_{3}+\mathrm{Fe}_{2} \mathrm{O}_{3}$ & $71.4 \%$ & 50 (min.) \\
$\mathrm{SO}_{3}$ & $2.5 \%$ & 5 (max.) \\
Loss on ignition & $4.1 \%$ & 6 (max.) \\
\hline
\end{tabular}

The hypothesis is that the SDBA (with oxides $\mathrm{SiO} 2, \mathrm{Al} 2 \mathrm{O} 3$ and $\mathrm{Fe} 2 \mathrm{O} 3$ in amorphous state and/or thermodynamically metastable and stable states of the structural links), in the presence of the cement and water, will react with calcium hydroxide to form part of the $\mathrm{CSH}$. That CSH originates from the system Portland cement, pozzolan and water, similar to that produced by the hydration of calcium silicates such as tricalcium silicates $\left(\mathrm{C}_{3} \mathrm{~S}\right)$. Thus, it is assumed that the amount of oxides $\left(\mathrm{SiO}_{2}, \mathrm{Al}_{2} \mathrm{O}_{3}\right.$ and $\left.\mathrm{Fe}_{2} \mathrm{O}_{3}\right)$ will influence the hydration process of the cement, in the volume of CSH formed in the system (cement, pozzolan and water), as well as the dynamic relationship of the ratio $\mathrm{Ca} / \mathrm{Si}$ of the CSH (KORPA et al., 2008; THOMAS et al., 2009; BULLARD et al., 2011).

The X-ray diffractograms of RHA and SDBA are shown in Figures 2 and 3, respectively, where the intensity is in photon count per second (cps) and $2 \theta$ indicates the angle of Bragg.

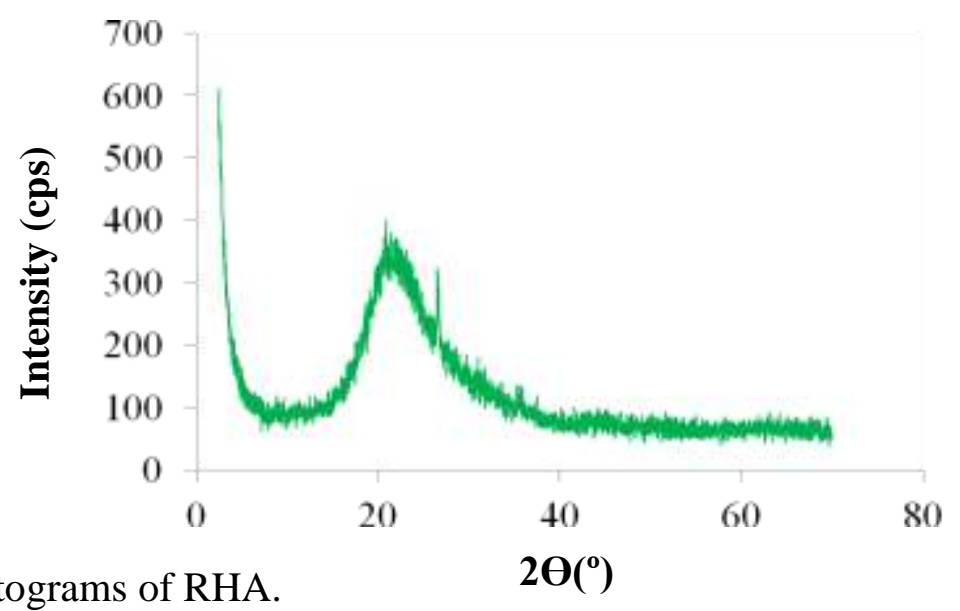

FIGURE 2. Diffractograms of RHA.

Figure 2 shows that there is an absence of peaks associated to the occurrence of crystalline phases. Moreover, it appears that there is a wideband between angles $2 \theta$ of 15 to $35^{\circ}$, indicating the presence of amorphous material. 


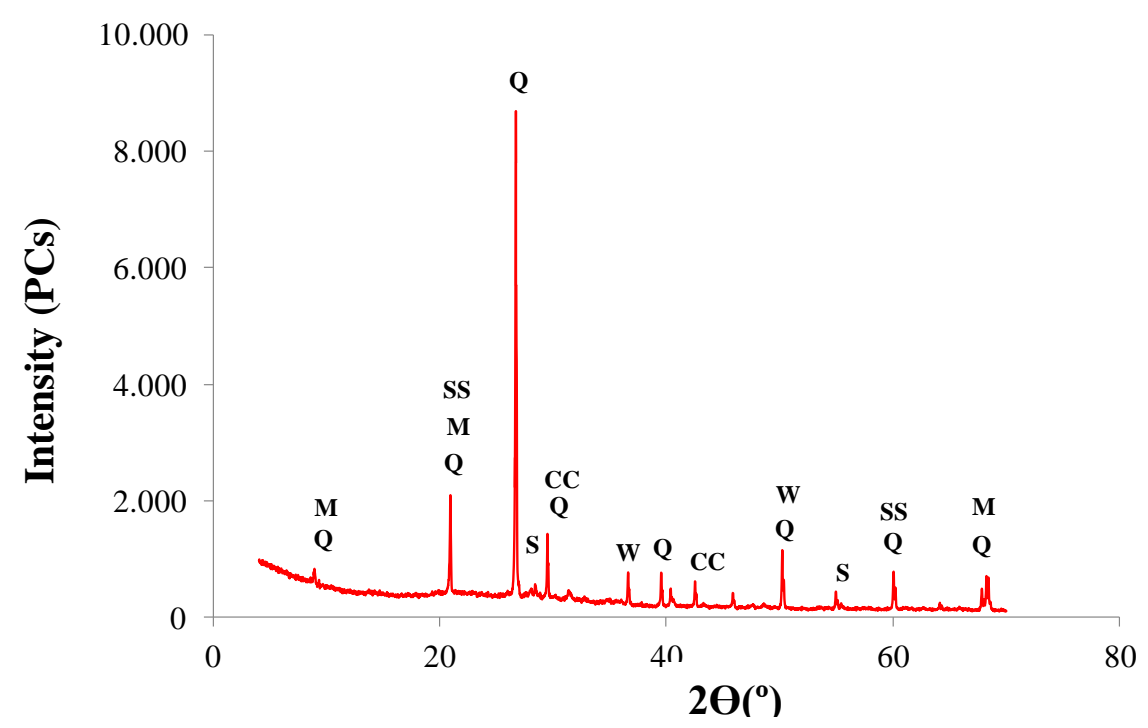

$* \mathbf{Q}\left(\mathrm{Quartz}: \mathrm{SiO}_{2}\right), \mathbf{S S}$ (Sodium sulfate: $\left.\mathrm{Na}_{2} \mathrm{~S}_{2} \mathrm{O}_{3}\right), \mathbf{C C}\left(\mathrm{Calcium}\right.$ carbonate: $\left.\mathrm{CaCO}_{3}\right), \mathbf{W}$ (Whitlockite:
$\left.\mathrm{Ca}_{18,19} \mathrm{Mg}_{1,17} \mathrm{Fe}_{0,83} \mathrm{H}_{1,62}\left(\mathrm{PO}_{4}\right)_{14}\right), \mathbf{M}$ (Muscovite: $\left.(\mathrm{K}, \mathrm{Na})(\mathrm{Al}, \mathrm{Mg}, \mathrm{Fe})_{2}\left(\mathrm{Si}_{3,1} \mathrm{Al}_{0,9}\right) \mathrm{O}_{10}(\mathrm{OH})_{2}\right), \mathbf{S}$ (Sylvite: $\left.\mathrm{KCl}\right)$.

FIGURE 3. X-ray diffraction pattern of SDBA.

The amorphicity favors the pozzolanic activity of the RHA according to NAIR et al. (2006). For the SDBA (Figure 3), it was observed that there is presence of crystalline phases, especially the quartz $\left(\mathrm{SiO}_{2}\right)$ and calcium carbonate $\left(\mathrm{CaCO}_{3}\right)$. However, it may be observed some amorphicity of the material indicated by the $2 \theta$ range between 15 and $35^{\circ}$. The crystalline phases of the SDBA suggest materials as the rest of feed and manure coming from the culture of pigs.

Figure 4 and Table 4 show the distributions and the main granulometric characteristics of particles of cement PC V-ARI, RHA, the SDBA and sand.

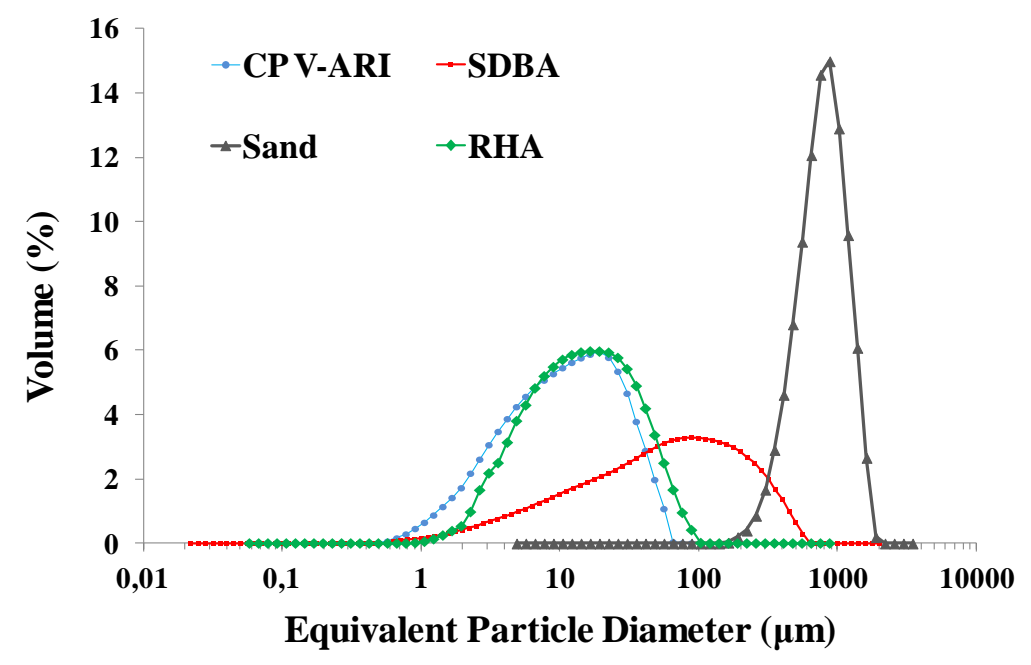

FIGURE 4. Particle size distribution of the raw materials after milling operation.

The set of distributions of equivalent diameter of the particles shown in Figure 4 at first facilitates the packing of the particles in the formulations of the composites. To take advantage of the optimization of packaging, it is necessary to define correctly the content ( $\%$ by mass and \% by volume) of each raw material (OLIVEIRA et al., 2000). However, the study of the best packing condition of the particles was not performed in this experimental work.

According to Table 5, the RHA has finer particles compared to the particules of SDBA, since $90 \%$ of the RHA particles have an equivalent diameter lower than $39.7 \mathrm{um}$, and the corresponding diameter for the SDBA is $243.3 \mu \mathrm{m}$. The finer the particle the greater the reactivity of the ashes (CORDEIRO, 2009). 
TABLE 5. Characteristics of the particle size distributions of the raw materials.

\begin{tabular}{lcc}
\hline Raw Material & $\mathrm{D}_{50}(\mu \mathrm{m})$ & $\mathrm{D}_{90}(\mu \mathrm{m})$ \\
\hline PC V-ARI & 10.11 & 30.23 \\
SDBA & 50.81 & 243.25 \\
Sand & 727.68 & 1169.19 \\
RHA & 13.19 & 39.69 \\
\hline
\end{tabular}

* D50 and D90 mean, respectively, $50 \%$ and $90 \%$ of the material containing particles smaller than the corresponding size indicated.

In Figure 5, it can be seen by scanning electron microscopy that the particles of RHA (Figure 5a) are smaller than the SDBA (Figure 5b) ones, as observed in the particle size distribution presented in Figure 4. In Figure 5b, the presence of angularity of the particles may be attributed to the milling process and the "memory" of the original structure of the vegetable, which favors a greater internal porosity of the ash particles.

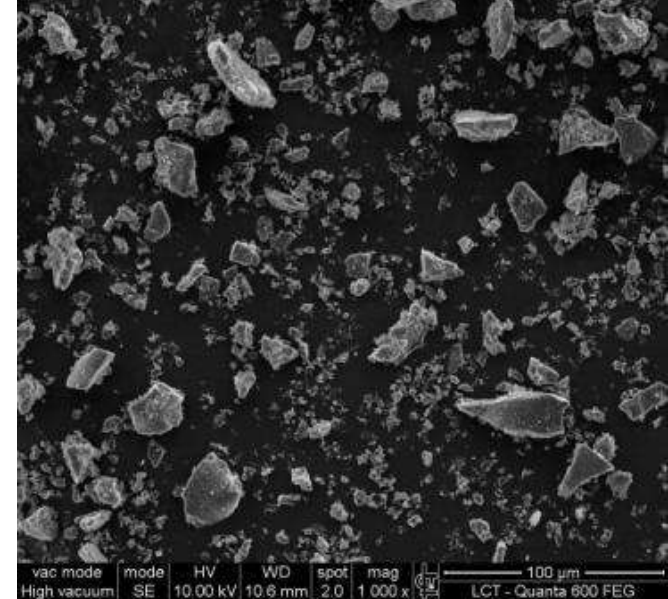

(a)

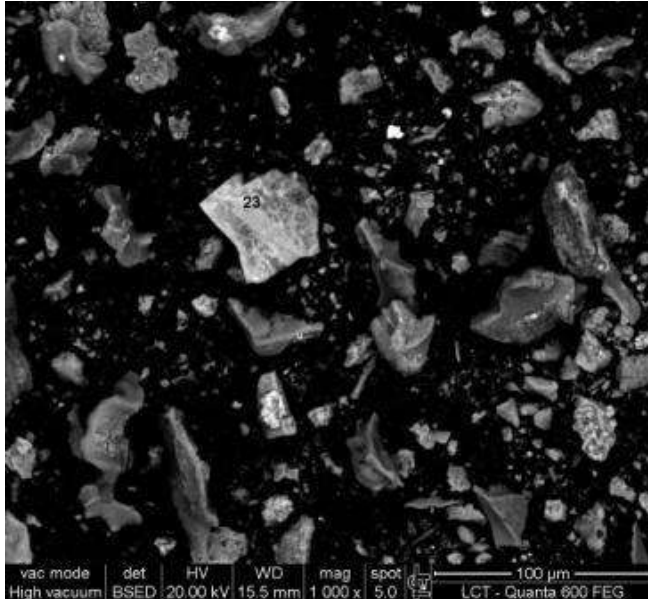

(b)

FIGURE 5. Scanning electronic microscopy of the RHA (a) and SDBA (b).

Figure 6 shows the scanning electron microscopy of a particle of SDBA and the related EDS analyses.

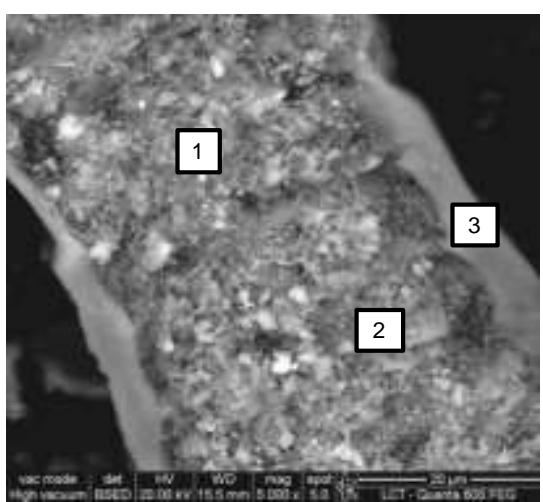

(a)

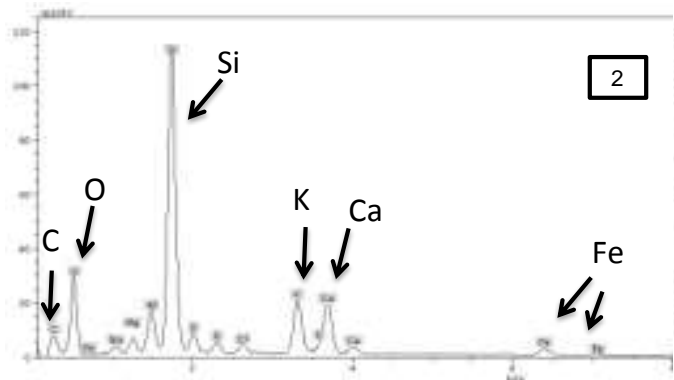

(c)

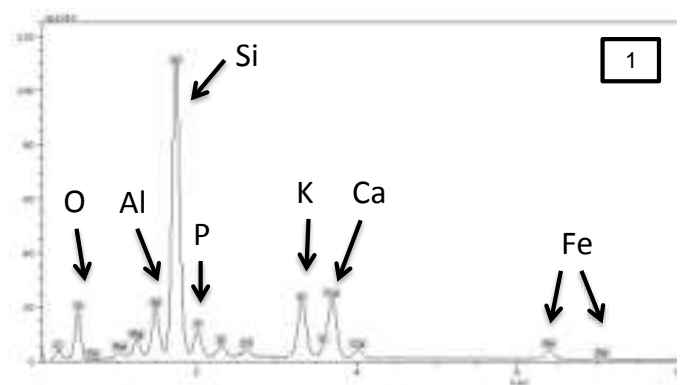

(b)

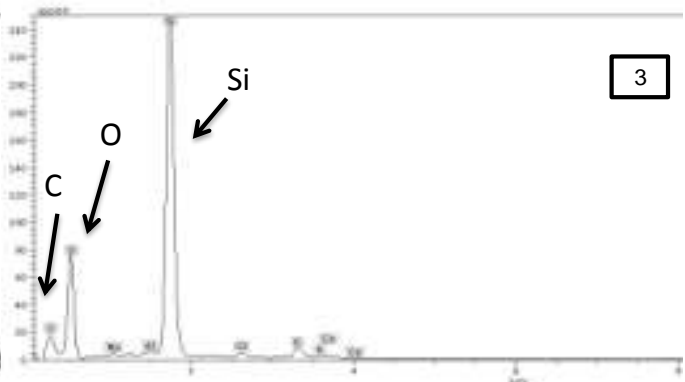

(d)

FIGURE 6. (a) Highlights of the internal (1) and (2) and external (3) layers of the SDBA, and (b) 
EDS in the region 1, (c) region 2 and (d) region 3.

Figure 7 shows the graph of the electrical conductivity of the solution $\mathrm{CH} / \mathrm{RHA}$ and $\mathrm{CH} / \mathrm{SDBA}$. Considering the characterizations of the RHA and the SDBA, we may infer that the RHA proved to be an amorphous material with high fineness and high content of $\mathrm{SiO}_{2}$, presenting thus high reactivity when in contact with calcium hydroxide $(\mathrm{CH})$.

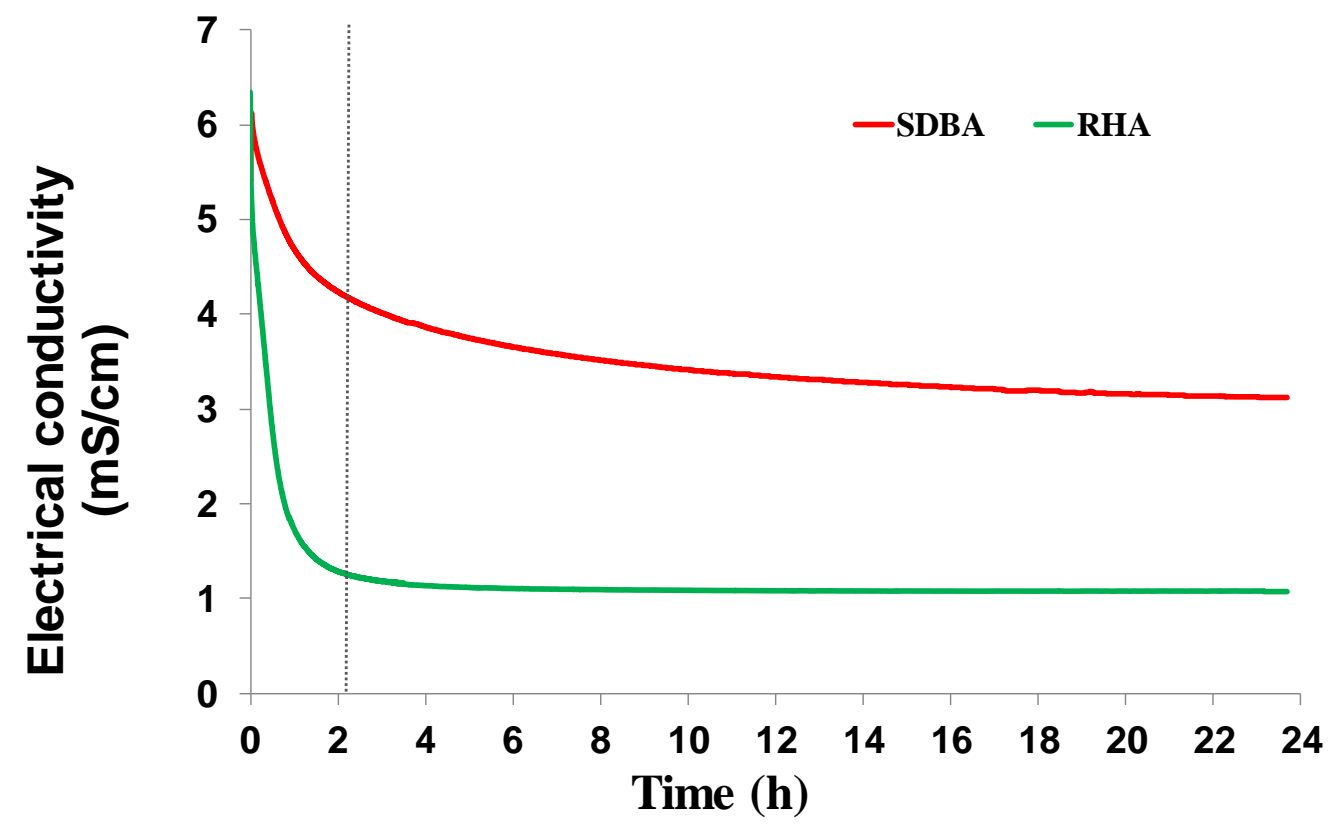

FIGURE 7. Electrical conductivity curves of the system of calcium hydroxide with SDBA or RHA.

According to METHA \& MONTEIRO (1994), the pozzolanic reaction is slow, but it is possible to compare the degree of reactivity of the ashes. The pozzolanic activity of RHA is characterized by the ability of silica (in an amorphous state), present in mixtures with cement or lime, to solubilize in alkaline environment, reacting in solution with calcium ions.

The SDBA showed up as a crystalline material and with particles with a diameter greater than the equivalent presented by RHA and the cement PC V-ARI. Thus, the curve of solution CH/RHA showed a stronger reactivity rate, because in the first two hours the electrical conductivity decreased rapidly and stabilized at about $1 \mathrm{mS} / \mathrm{cm}$. The solution $\mathrm{CH} / \mathrm{SDBA}$ showed a lower rate of reactivity compared with RHA, since the values of electrical conductivity reduced slowly to around $4.2 \mathrm{mS} / \mathrm{cm}$ in the same period and stabilized at around $3 \mathrm{mS} / \mathrm{cm}$ after approximately $10 \mathrm{~h}$.

\section{Physical and mechanical characterization of composites}

The results of physical testing of composites are shown in Table 6.

TABLE 6. Mean values of physical properties, apparent water absorption (WA), apparent density (AD) and apparent porosity (AP) of the composites.

\begin{tabular}{lrccccc}
\hline & \multicolumn{2}{c}{ WA $(\%)$} & \multicolumn{2}{c}{$\mathrm{BD}\left(\mathrm{g} / \mathrm{cm}^{3}\right)$} & \multicolumn{2}{c}{$\mathrm{AP}(\%)$} \\
\hline Age (days) & 10 & 28 & 10 & 28 & 10 & 28 \\
\hline Reference & $9.9^{\mathrm{a}}$ & $10.1^{\mathrm{a}}$ & $2.0^{\mathrm{b}}$ & $2.0^{\mathrm{b}}$ & $18.5^{\mathrm{a}}$ & $20.4^{\mathrm{a}}$ \\
Cement + SDBA & $10.4^{\mathrm{b}}$ & $11.0^{\mathrm{b}}$ & $1.9^{\mathrm{a}}$ & $1.9^{\mathrm{a}}$ & $20.1^{\mathrm{b}}$ & $21.2^{\mathrm{a}}$ \\
\hline
\end{tabular}

*Mean values with different letters in the same column differ statistically from Tukey Test, $\mathrm{P}<0.05$.

By Tukey test $(\mathrm{P}<0.05)$, the composite with ashes has higher water absorption (WA) when compared with the composite without SDBA (reference). However, The bulk density (BD) of the composite reference is statistically higher, and this may be due to incorporation of the ash in the composite. Regarding porosity (AP), it is noted that the composite SDBA showed a value 
statistically greater than the reference, at 10 days of age. At 28 days of age, there was no difference, and this may be due to hydration reactions in both composites. Table 7.

The mechanical properties obtained from the mechanical tests of the composites are listed in

TABLE 7. Mean values of mechanical properties of composites.

\begin{tabular}{lcccc}
\hline & \multicolumn{2}{c}{ MOR $(\mathrm{MPa})$} & \multicolumn{2}{c}{ MOE $(\mathrm{GPa})$} \\
\hline Age (days) & 10 & 28 & 10 & 28 \\
\hline Reference & $5.3^{\mathrm{a}}$ & $5.0^{\mathrm{a}}$ & $13.2^{\mathrm{a}}$ & $14.0^{\mathrm{a}}$ \\
Cement + SDBA & $4.0^{\mathrm{b}}$ & $5.2^{\mathrm{a}}$ & $9.9^{\mathrm{b}}$ & $11.0^{\mathrm{b}}$
\end{tabular}

*MOR: Modulus of Rupture; MOE: Modulus of elasticity. *Mean values with different letters in the same column differ statistically from Tukey Test, $\mathrm{P}<0.05$.

The modulus of rupture is related to the mechanical strength of the composite under bending stresses. By Tukey test $(\mathrm{P}<0.05)$, mean values of MOR of composites at 10 days of age the composite with SDBA has a lower mechanical performance compared to reference, as noted in Table 7 and through the typical curve stress versus specific deformation (Figure 8a), which indicates that the reference composite reaches higher deformation than that with the SDBA. The reactivity of mineral additions with Portland cement depends on factors such as morphology, amorphicity, size distribution and chemical composition (CORDEIRO, 2009). Thus, the low mechanical performance of the composite at 10 days of age may be related to the slower reactivity of the swine deep bedding ashes, as indicated in electric conductivity test (Figure 7) and due to impurities presented by SDBA (Table 3). However, after 28 days the mean values of MOR indicate that both composites have the same tensile strength in bending (Table 7 and Figure 8b). Figure 8b also shows that the composite with SDBA has lower modulus of elasticity than the reference.

The modulus of elasticity (MOE) is directly related to the stiffness of the composite. With this, the reference formulation is more rigid than with ashes (SDBA), 33\% at 10 days and $27 \%$ at 28 days of age, according to the mean values listed in Table 7 and according to the steepness of the curves stress versus specific deformation in the elastic region (Figures $8 \mathrm{a}$ and $8 \mathrm{~b}$ ).

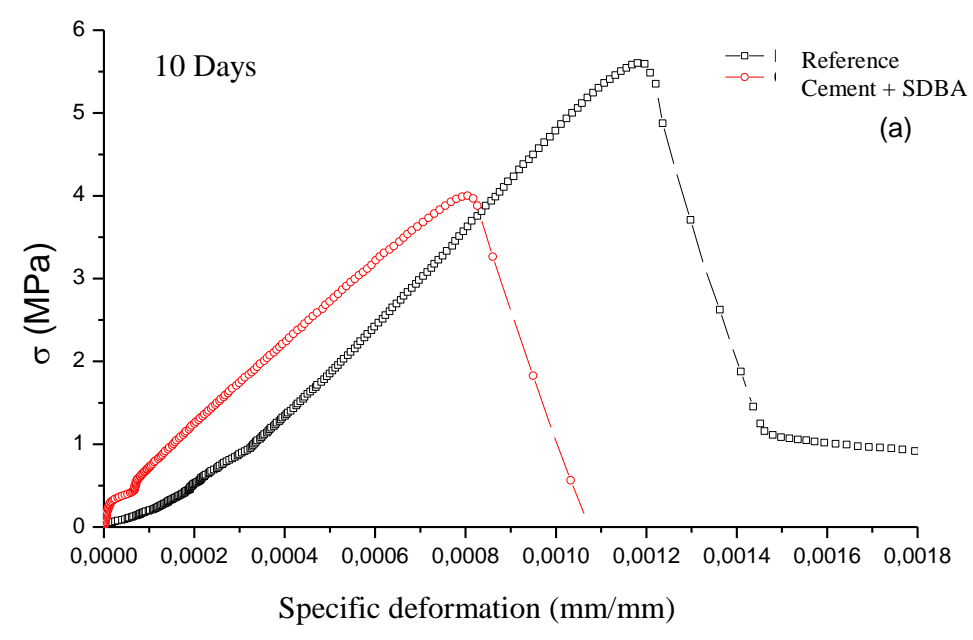




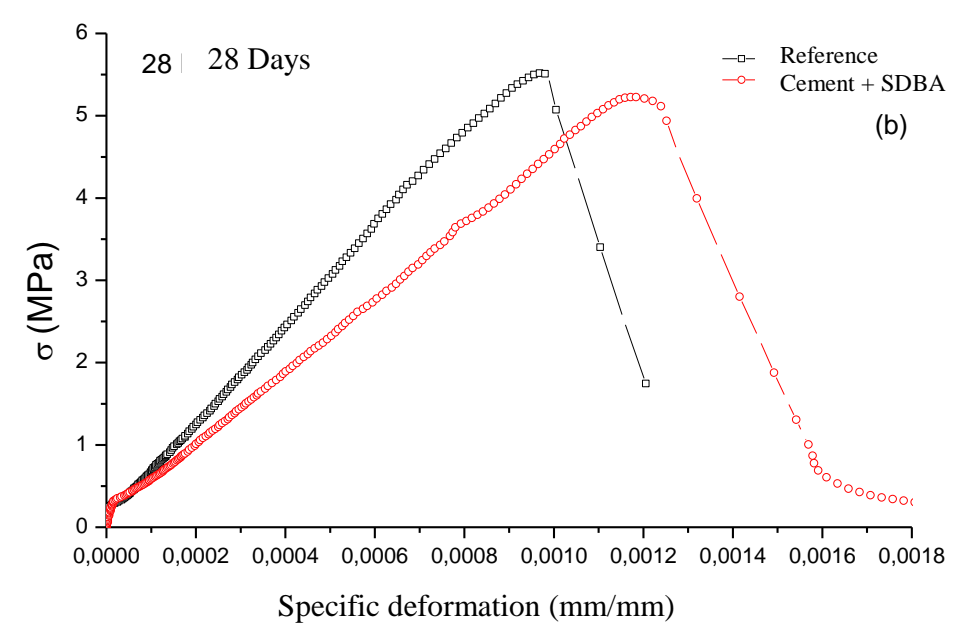

FIGURE 8. Typical curves of bending stress versus specific deformation of the reference composites and cement + SDBA composites at ages 10 (a) and 28 (b) days.

By NBR 15498 (2007), the mechanical performance of plates with SDBA may be classified as Class A, Category $2(4 \mathrm{MPa})$. Thus, according to the characterizations made and standard mentioned, these composites may be used in farm buildings.

\section{CONCLUSIONS}

By chemical and physical characteristics of the ashes evaluated, it is concluded that rice husk ashes (RHA) tested in this study are considered amorphous material with high fineness and high content of $\mathrm{SiO}_{2}$. The electrical conductivity showed high reactivity when in contact with calcium hydroxide $(\mathrm{CH})$ in relation to swine deep bedding ashes (SDBA). The swine deep bedding ashes (SDBA) were crystalline particles with a equivalent diameter higher, due to the incorporation of the materials coming from the production of pigs, than those presented by the RHA and the Portland cement PC V-ARI. According to NBR 15498 (2007), the physical and mechanical characterizations obtained in this work it is possible to indicate the use of composites with SDBA in rural buildings.

\section{ACKNOWLEDGEMENTS}

The Foundation for Research Support of the State of São Paulo (FAPESP) for granting the master's scholarship, the productivity scholarship by $\mathrm{CNPq}$ and São Paulo's Agency for Agribusiness Technology (APTA) for providing the swine deep bedding.

\section{REFERENCES}

ABNT. Associação Brasileira de Normas Técnicas. NBR 5733: Cimento Portland de alta resistência inicial. Rio de Janeiro, 1991.

. NBR 7214: Areia normal para ensaio de cimento. Rio de Janeiro, 1982.

. NBR 15498: Placa plana cimentícia sem amianto: requisitos e métodos de ensaio. Rio de Janeiro, 2007.

ASTM. American Society for Testing And Materials - ASTM C618-03. Standard specification for coal fly and raw or calcined natural pozzolan for use as a mineral admixture in concrete. West Conshohocken, 2003. 
BULLARD J. W.; JENNINGS H. M.; LIVINGSTON R. A.; NONAT A.; SCHERER G. W.; SCHWEITZER J. S.; SCRIVENER K. L.; THOMAS J. J. Mechanisms of cement hydration. Cement and Concrete Research, v.41, p.1208-1223, 2011.

CALLISTER JR., W. D. Materials science and engineering: an introduction. $7^{\text {th }}$ ed. New Jersey: John Wiley \& Sons, 2007. 721 p.

CINCOTTO, M.A.; KAUPATEZ, R.Z. Seleção de materiais quanto à atividade pozolânica. In: IPTInstituto de Pesquisas Tecnológicas. Tecnologia de edificações. São Paulo: Pini, 1988. p.23-26.

CORDEIRO, G. C.; TOLEDO FILHO, R. D.; TAVARES, L. M.; FAIRBAIRN, E. M. R. Ultrafine grinding of sugar cane bagasse ash for application as pozzolanic admixture in concrete. Cement and Concrete Research, Elmsford, v.39, p.110-115, 2009.

DI CAMPOS, M. S. Placas planas à base de cinza de cama sobreposta de suínos e fibra de sisal para piso de escamoteadores com diferentes fontes de aquecimento. 2010. $156 \mathrm{f}$. Tese (Doutorado)

- Faculdade de Zootecnia e Engenharia de Alimentos, Universidade de São Paulo, Pirassununga, 2010.

JOHN, V. M.; CINCOTTO, M. A.; SILVA, M. G. Cinzas e aglomerantes alternativos. In: FREIRE, W.J.F. LUDOVICO, B. (Coord.). Tecnologia e materiais alternativos de construção. Campinas: Editora da UNICAMP, 2003. p.145-190.

KORPA, A.; KOWALD, T.; TRETTIN R. Hydration behaviour, structure and morphology of hydration phases in advanced cement-based systems containing micro and nanoscale pozzolanic additives. Cement and Concrete Research, Elmsford, v.38, p.955-962, 2008.

MEHTA, P.K.; MONTEIRO, P.J.M. Concreto, estruturas, propriedades e materiais. São Paulo: Pini, 1994. 574 p.

NAIR, D. G.; JAGADISH, K. S.; FRAAIJ, A. Reactive pozzolanas from Rice husk ash: An alternative to cement for rural housing. Cement and Concrete Research, Elmsford, v.36, p.10621071, 2006.

OLIVEIRA, D. C. G. Avaliação do microclima interno de abrigos escamoteadores com diferentes tipos de pisos. 2010. 119 f. Dissertação (Mestrado) - Faculdade de Zootecnia e Engenharia de Alimentos, Universidade de São Paulo, Pirassununga, 2010.

OLIVEIRA, I. R.; STUDART, A. R.; PILEGGI R. G.; PANDOLFELLI, V. C. Dispersão e empacotamento de partículas: Princípios e aplicações em processamento cerâmico. Ed. São Paulo: Fazendo Arte, 2000. 224 p.

OYEKAN, G. L.; KAMIYO, O. M.; A study on the engineering properties of sandcrete blocks produced with rice husk ash blended cement. Journal of Engineering and Technology Research, v.3, n.3, p.88-98, 2011.

PAYÁ, J.; BORRACHERO, M.V.; MONZÓ, J.; PERIS-MORA, E.; AMAHJOUR, F. Enhanced conductivity measurement techniques for evaluation of fly ash pozzolanic activity. Cement and Concrete Research, Elmsford, v.31, p.41-49, 2001.

POSSAN, E.; VENQUIARUTO, S. D.; MOLIN, D. C. C. D. Adição de cinza de casca de arroz no concreto: benefícios de durabilidade. In: ENCONTRO TECNOLÓGICO DA ENGENHARIA CIVIL E ARQUITETURA, 6., 2007, Maringá. Anais...

RILEM TECHNICAL COMMITTE 49 - TFR Draft Recommendations. Matériaux et Constructions, Paris, v.17, n.102, p.441-456, 1984.

RODRIGUES, M. F.; BERALDO, A. L. Caracterização física e mecânica de argamassas à base de cimento Portland e cinza de casca de arroz residual. Engenharia Agrícola, Jaboticabal, v.30, n.2, p.193-204, 2010. 
SAS INSTITUTE. SAS OnlineDoc® 9.1.3. Cary, 2006.

SOUZA, G. P.; FILGUEIRA, M.; ROSENTHAL, R.; HOLANDA, J. N. F. Caracterização de material compósito diatomáceo natural. Cerâmica, São Paulo, v.49, p.40-43, 2003.

THOMAS J. J.; JENNINGS H. M.; CHEN J. J. Influence of nucleation seeding on the hydration mechanisms of tricalcium silicate and cement. Journal of Physical Chemistry, Washington, v.113, p.4327-4334, 2009.

TONOLI, G. H. D.; JOAQUIM, A. P.; ARSÈÈNE, M. A.; BILBA, K.; SAVASTANO JR, H. Performance and durability of cement based composites reinforced with refined sisal pulp. Materials and Manufacturing Processes, v.22, p.149-156, 2007. 